\title{
VIOLAÇÕES AOS DIREITOS HUMANOS DOS TRABALHADORES E OS SISTEMAS REGIONAIS DE PROTEÇÃO
}

VIOLATIONS TO WORKER'S HUMAN RIGHTS AND REGIONAL PROTECTION SYSTEMS

\author{
Flávia Cristina Piovesan ${ }^{1}$ \\ Regeane Bransin Quetes ${ }^{2}$ \\ Miriam Olivia Knopik Ferraz ${ }^{3}$
}

Resumo: Neste artigo teve-se como objetivo a análise da violação dos direitos humanos dos trabalhadores e o papel dos sistemas regionais de proteção. A metodologia foi o exame da jurisprudência do sistema Interamericano, o sistema Europeu e o sistema Africano dentro de uma perspectiva que buscou a análise a partir da universalidade e indivisibilidade dos direitos humanos, bem como de multifuncionalidade e dupla titularidade dos direitos humanos fundamentais. Por meio da análise dos casos que são direcionados à proteção e direitos trabalhistas, observou-se que os sistemas, ainda, não são harmônicos quanto à jurisprudência trabalhista. Os sistemas Interamericano e Europeu fundamentam suas decisões pelos direitos individuais, usando uma interpretação extensiva, permitindo o entendimento da multifuncionalidade, da dupla titularidade e da interdependência dos direitos. No sistema Africano, direitos civis e sociais foram contemplados num mesmo patamar, mas ainda é preciso aguardar uma postura menos formalista do sistema para que conclusões possam ser tomadas. Espera-se que tais sistemas tenham a capacidade de avançar na proteção mais plena e efetiva dos direitos trabalhistas - condição essencial à própria prevalência da dignidade humana.

Palavras-chave: Sistema de proteção de direitos humanos. Direitos humanos dos trabalhadores. Direitos sociais. Proteção internacional. Direitos fundamentais.
Abstract: The objective of this article was to analyze the violation of workers' human rights and the role of regional protection systems. The methodology was the examination of the jurisprudence of the Inter-American system, the European system and the African system, from a perspective that sought the analysis from the universality and indivisibility of human rights, as well as multifunctionality and dual ownership of fundamental human rights. Through the analysis of the cases that are directed to the protection and labor rights, it was observed that the systems are still not harmonious regarding labor jurisprudence. The Inter-American and European systems base their decisions on individual rights, using an extensive interpretation, allowing the understanding of multifunctionality, dual ownership and the interdependence of rights. In the African system, civil and social rights were on the same footing, but we still have to wait for a less formalist stance of the system in order to reach conclusions. Such systems are expected to have the potential to advance the fullest and most effective protection of labor rights - an essential condition for the very prevalence of human dignity.

Keywords: Human rights protection system. Human rights of workers. Social rights. International protection. Fundamental rights.

\footnotetext{
1 Doutora e Mestre em Direito Constitucional e Direitos Humanos da Pontifícia Universidade Católica de São Paulo; Professora de Direitos Humanos nos Programas de Pós-Graduação da Pontifícia Universidade Católica de São Paulo, da Pontifícia Universidade Católica do Paraná e da Universidade Pablo de Olavide; Rua Imaculada Conceição, 1155, Prado Velho, 80215901, Curitiba, Paraná, Brasil; flaviapiovesan@terra.com.br

2 Mestre em Direito Econômico e Socioambiental pela Pontifícia Universidade Católica do Paraná; Especialista em Direito Administrativo pelo Instituto de Direito Romeu Felipe Bacellar; regeane@bransinquetes.adv.br

3 Mestranda em Direito pela Pontifícia Universidade Católica do Paraná; pós-graduanda em Direito Constitucional pela Academia Brasileira de Direito Constitucional; Secretária Executiva da Revista de Direito Econômico e Socioambiental do PPGD da Pontifícia Universidade Católica do Paraná; m.okf@hotmail.com
} 


\section{Introdução}

Os sistemas de proteção de direitos humanos podem ser globais ou regionais. O sistema Global tem início com a Declaração de Direitos Humanos, que adota a concepção contemporânea de Direitos Humanos, após a necessidade de proteção dos indivíduos contra inúmeras atrocidades ocorridas. Com os Pactos Adicionais nasce a Carta de Direitos Humanos, um sobre direitos individuais e Políticos, e outro sobre Direitos Sociais, Culturais e Econômicos.

Os sistemas globais convivem harmoniosamente com o sistema regional, trazendo os direitos humanos às suas realidades regionais, com o objetivo de ampliá-los e não os reduzir. No presente trabalho serão analisados os sistemas Interamericano, Europeu e Africano.

Cada sistema tem seu Documento constitutivo: o sistema Interamericano tem como documento central a Convenção Americana de Direitos Humanos, o sistema Europeu, a Convenção Europeia, e o Africano, a Carta Africana de Direitos Humanos e dos Povos. Este foi o único sistema que uniu num só documento Direitos Individuais, Políticos, Sociais, Econômicos e Culturais, enquanto os sistemas Interamericano e Europeu aderiram a um pacto adicional em matéria de direitos sociais, econômicos e culturais num segundo momento.

A concepção contemporânea de Direitos Humanos entende os direitos como universais e indivisíveis. Ao presente trabalho a característica de indivisibilidade permeia toda a discussão, ao passo que defende a interdependência e a complementação dos direitos, não havendo, assim, uma divisão entre individuais e sociais, que demandem de prestações positivas ou negativas, pois todos os direitos possuem um feixe de posições positivo e negativo. Assim como todos possuem uma titularidade coletiva e individual, quanto a esse aspecto o trabalho se baseia nos ensinamentos de Daniel Wunder Hachem (2013, p. 618-688).

Será analisado o posicionamento desses sistemas quanto à violação de direitos humanos trabalhistas que são exemplos clássicos da característica de multifuncionalidade e dupla titularidade. Para tanto, o artigo se divide em quatro seções: a primeira trata brevemente do sistema global de proteção de direitos humanos; a segunda versa sobre os sistemas regionais citados anteriormente e sua relação com os direitos sociais; na terceira seção são descritos casos e posicionamentos dos três sistemas em que se discorre sobre direitos dos trabalhadores de forma direta ou indireta, comprovando a preferência dos direitos individuais nos argumentos dos julgadores; por fim, realiza-se a análise dos casos, sobretudo quanto à ideia de indivisibilidade dos direitos humanos, de forma a demonstrar que não há uma separação estanque dos direitos.

\section{Considerações sobre o sistema global de direitos humanos}

No segundo pós-guerra o mundo sente a necessidade de mecanismos de combate a governos totalitários, nascendo, assim, a internacionalização dos direitos humanos (LACERDA, 
2014, p. 106). A Declaração Universal de Direitos Humanos foi o primeiro documento criado em âmbito internacional -, mas por se tratar de declaração não era dotado em si mesmo de eficácia jurídica. Dessa forma, houve processo de judicialização quando a Declaração se tornou vinculativa e obrigatória. Esse processo teve início em 1949 e fim em 1966, quando foram incorporados dois tratados internacionais ao documento - o Pacto de Direitos Civis e Políticos e o Pacto dos Direitos Sociais, Econômicos e Culturais - dando origem à Carta Internacional de Direitos Humanos (PIOVESAN, 2011, p. 215).

A Carta Internacional representa o marco inicial do sistema global de proteção dos direitos humanos, que foi ampliado após inúmeros tratados multilaterais que objetivam a mínima proteção dos indivíduos, suas liberdades e direitos fundamentais, com responsabilidade de caráter subsidiário. Enquanto a legislação interna de cada país possui responsabilidade de natureza primária, podendo estabelecer maior proteção, mas nunca menor que aquelas estabelecidas pelos tratados internacionais (PIOVESAN, 2011, p. 216-217).

A Declaração Universal de Direitos Humanos exprime a concepção contemporânea dos direitos humanos, definindo-os como universais e indivisíveis. Isto é, os direitos humanos devem ser garantidos a quaisquer pessoas, sendo o resultado da união entre os direitos civis e políticos e os direitos econômicos, sociais e culturais, que devem ser conjuntamente protegidos, pois a violação de um direito individual, por exemplo, implica violação a todos (PIOVESAN, 2005, p. 44-45).

Importa realçar que o caráter de indivisibilidade dos direitos humanos toma especial importância para o presente trabalho, pressuposto extremante pertinente quando da análise jurisprudencial.

No que se refere ao direito dos trabalhadores, que é objeto do presente, cabe mencionar a Organização Internacional do Trabalho (OIT), que passa a existir em 1919, mediante o Tratado de Versalhes, com o papel de cessar a Primeira Guerra Mundial, com fundamentos na "justiça social", e após o nascimento da ONU, em 1945, torna-se sua primeira agência especializada (ORGANIZAÇÃO INTERNACIONAL DO TRABALHO, 2015).

Após esses primeiros esclarecimentos, adentra-se no foco do artigo - os sistemas de proteção de direitos humanos - que podem ser globais ou regionais. Os primeiros surgem a partir da ideia de universalização de direitos humanos, em que a preocupação se torna internacional, havendo, portanto, necessária reavaliação quanto à noção de soberania do Estado e a criação de sistemas internacionais denominados international accontability (PIOVESAN, 2011, p. 215) .

Os sistemas regionais nascem contemporaneamente ao sistema global. E a experiência comprova que convivem harmonicamente, cabendo ao sistema global, às proteções mínimas e aos sistemas regionais em conjunto com a legislação nacional a observância das peculiaridades de cada região, bem como ampliação protetiva, em conformidade com a Declaração Universal de Direitos Humanos. Porém, por contar com um número menor de países-membros com realidades e identi- 
dades culturais mais próximas, apresentam contexto político mais consensual e com mais sucesso quanto à efetividade na aplicação de sanções (PIOVESAN, 2011, p. 205, 306-309).

Em síntese, o sistema de proteção de direitos humanos é composto pelos sistemas globais e regionais, que convivem harmoniosamente. Os principais sistemas regionais são o Europeu, o Interamericano e o Africano, nesta ordem do mais antigo ao mais recente, cada qual com suas peculiaridades, em consequência da realidade dos continentes, momento de instituição e criação, mas também com similitudes, como será a seguir enfocado.

\section{Sistemas regionais de proteção de direitos humanos e os direitos sociais}

O sistema Interamericano tem como instrumento central a Convenção Americana de Direitos Humanos, sendo instituída em 1978, também conhecida como Pacto de São José da Costa Rica. Esse é o sistema do qual o Brasil é membro e surge em meio a um contexto de ditadura na América Latina, mais especificamente metade dos Estados-partes à época eram comandados por governos autoritários. Uma realidade completamente distinta do momento de criação do sistema Europeu (PIOVESAN, 2012, p. 13).

É composto pela Comissão Interamericana de Direitos Humanos e pela Corte instituída em 1979 (COMISIÓN INTEREMERICANA DE DERECHOS HUMANOS, 1979), que conta com sete juízes de diferentes nacionalidades, desempenhando função contenciosa e consultiva que é exercida apenas em face dos Estados que a reconhecem. Ainda, cabendo-lhe a supervisão do cumprimento de decisões que detém caráter vinculante (CORTE INTERAMERICANA DE DERECHOS HUMANOS, 2018).

A Convenção Americana de Direitos Humanos continha em seu rol direitos classificados tradicionalmente como individuais, civis e políticos, somente em seu artigo 26 tratava da progressividade dos direitos sociais. Apenas no Pacto de San Salvador, em 1988, que houve preocupação com os demais direitos, entretanto, em seu artigo 19, dispunha ressalva de que exclusivamente os direitos à educação e liberdade sindical poderiam ser objeto de petições individuais (PIOVESAN, 2012, p. 13).

No caso Villagran Morales Vs Guatemala foi a primeira vez em que a corte apresentou o posicionamento aqui já defendido, no sentido de que os direitos humanos possuem dimensões positiva e negativa (PIOVESAN, 2012, p. 13). Fundamento que possibilitou a extensão da proteção aos direitos sociais, posteriormente foi pincelado em diversos outros casos, tratando dos direitos sociais de forma indireta, mas consagrando a indivisibilidade dos direitos humanos, por meio de aplicação "interpretação evolutiva", denominada living instruments, segundo Piovesan (2012, p. 13).

Note-se que a Convenção americana foi ratificada por 25 Estados-membros; a Convenção Interamericana para Prevenir, Punir e Erradicar a Violência contra a Mulher de 1994, por 31 Estados; enquanto o Protocolo sobre Direitos Humanos em Matéria de Direitos Econômicos, Sociais e Cul- 
turais, de 1988, teve adesão tão somente de 14 Estados, ou seja, 56\% dos Estados que ratificaram a Convenção Americana (BENVENUTO; SILVA, 2011).

Esses dados evidenciam a resistência dos Estados-Partes quanto à adoção de tratados que versem sobre direitos sociais, e corroboram os problemas enfrentados no que tange à efetivação desses direitos tanto no plano internacional quanto no plano doméstico.

Em contexto completamente diverso do sistema Interamericano, o sistema Europeu surge no segundo pós-guerra, como uma esperança de mínima proteção aos direitos humanos do continente Europeu. A "Convenção Europeia para Proteção de Direitos Humanos e das Liberdades Fundamentais" entrou em vigor em 1953, sendo o principal documento desse sistema regional, que teve seu rol de direitos ampliado após a adoção de diversos protocolos (MAZZUOLI, 2010, p. 34).

A Corte Europeia proferiu sua primeira sentença em 1960 (Caso Lawless Vs Irlanda), e ganhou novo formato a partir do Protocolo 11, em que foram unificadas a Comissão e a Corte, brotando, assim, um órgão único e responsável tanto pela admissibilidade quanto pelo mérito. A mudança mais relevante após o Protocolo 11 concerne à possibilidade dos indivíduos e organizações ao acesso direto à corte em casos de violações a direitos humanos (MAZZUOLI, 2010, p. 40).

Infelizmente tal avanço não pode ser sentido pela Corte Interamericana de Direitos Humanos, pois, diferentemente do sistema Europeu, a vítima tão somente pode participar do processo, ficando dependente da intervenção da Comissão Americana para que haja o ingresso de demandas em desfavor dos Estados violadores (MAZZUOLI, 2010, p. 41). A possibilidade de os indivíduos e organizações ingressarem com demandas em desfavor dos Estados implicou aumento significativo de demandas levadas à Corte Europeia, ao passo que a "nova corte", assim denominada, após o protocolo, em dois anos de funcionamento proferiu 838 decisões, enquanto a antiga corte, em 39 anos de vigência, proferiu 837 decisões (MAZZUOLI, 2010, p. 42-43).

A nova corte Europeia é composta pelo mesmo número de juízes que seus 45 Estados-Partes, tendo competência consultiva e contenciosa e com sentenças de natureza vinculante ou declaratória, que posteriormente serão supervisionadas pelo Comitê de ministros, que poderá aplicar sanções em caso se descumprimento, chegando até mesmo à pena de expulsão (MAZZUOLI, 2010, p. 44-45).

Apesar da existência de disposições anteriores sobre direitos sociais, estes passaram a ter visibilidade no sistema regional Europeu com a adoção da Carta Comunitária dos Direitos Sociais dos Trabalhadores em 1989 (COMISSÃO DAS COMUNIDADES EUROPEIAS, 1990), do Tratado de Amsterdã em 1997, e da nova Carta Social Europeia em 1999. Entretanto, a aplicação dos direitos sociais também encontra grande resistência e enfrenta inúmeros obstáculos (MIALON, 2005, p. 51).

Segundo Angelika Nussberger, juíza da Corte Europeia, a Carta Europeia de Direitos Sociais é um "elo fraco", pois existe apenas um comitê de direitos sociais, em que suas decisões não são vinculantes, valendo-se apenas como uma recomendação (NUSSBERGER, 2014). Mialon (2005, p. 
56) explica que havia expectativa de mudanças quanto aos "instrumentos jurídicos mais recentes", todavia isso não ocorreu.

Passando do mais antigo sistema para o mais recente, - o sistema regional Africano originou-se após debates da Organização da Unidade Africana em 1979, mas apenas em 1986 é que a Carta Africana, ou Carta de Banjul, entrou em vigor com a ratificação do número mínimo de países exigidos (BRANT; PEREIRA; BARROS, 2006, p. 6916-6917).

A Carta Africana foi precursora no tratamento dos direitos humanos na África, tendo como pilares: os direitos dos povos, o respeito aos direitos tribais e os direitos e deveres dos cidadãos em relação a sua família. A Comissão Africana dos Direitos Humanos e dos Povos é composta por 11 membros e inicialmente suas decisões possuíam caráter vinculativo, cabendo-lhe a promoção de direitos humanos, supervisão, recomendações e sugestões frente às violações de direitos, bem como competência interpretativa, dispostas no artigo 45 da Carta Africana (BRANT; PEREIRA; BARROS, 2006, p. 6920).

Apenas em 2004 é que o Protocolo Adicional à Carta Africana entra em vigor e surge a Corte Africana dos Direitos Humanos e dos Povos (TRIBUNAL AFRICANO DE DIREITOS HUMANOS E DOS POVOS, 2004), composto por 11 juízes, com competência consultiva e contenciosa, acesso direto dos indivíduos à corte, se o Estado declarar expressamente essa possibilidade, também sendo permitidas demandas não estatais (BRANT; PEREIRA; BARROS, 2006, p. 6926). Está em discussão a unificação entre a Corte Africana de Direitos humanos e a de justiça, havendo, assim, um único órgão com competência jurisdicional, o que seria uma inovação apresentada por esse sistema (AFRICAN INTERNATIONAL COURTS AND TRIBUNALS, 2018).

Em 2008 o Tribunal Africano recebe sua primeira petição, interposta pelo Sr. Michelot Yogogombaye contra a República do Senegal, e profere o primeiro acordão em 2009, exatamente nesse caso (TRIBUNAL AFRICANO DE DIREITOS HUMANOS E DOS POVOS, 2008).

O sistema Africano é conhecido por apresentar soluções inéditas, tanto que é o único sistema que tratou de direitos civis e políticos no mesmo documento que os direitos sociais, econômicos e culturais (BRANT; PEREIRA; BARROS, 2006, p. 6916). A esse respeito importante mencionar posicionamento de Valério Mazzuoli, segundo quem, ao tratar de direitos civis e políticos e direitos sociais, econômicos e culturais na mesma Carta, o sistema elevou tais direitos ao mesmo grau de efetividade, o que resulta "na proteção do indivíduo não só sob a ótica liberal ou individualista, mas sob a ótica social ou coletiva." (MAZZUOLI, 2012, p. 943).

Já os sistemas Europeu e Interamericano protegem prioritariamente os direitos individuais e políticos, passando a preocupar-se com os sociais após aderência de protocolos, mais especificamente no caso da Europa, por meio de e tratados específicos (MAZZUOLI, 2010, p. 54).

Em meio a várias diferenças, todos os sistemas têm um objetivo comum que se resume na proteção dos direitos humanos, assim como todos enfrentam dificuldades e obstáculos. A Corte Europeia quanto à elevação do número de petições; a Corte Interamericana no cumprimento das 
decisões e recomendações pelos Estados-Partes; e o sistema Africano, ainda muito recente, não pode ser avaliado quanto a sua eficácia (BICUDO, 2003, p. 233-234), mas pelas próprias condições de extrema pobreza em que vive o povo Africano e inúmeras violações de direitos humanos ocorridas cotidianamente não é difícil de imaginar que o sistema, igualmente, enfrentará diversos obstáculos. Embora estes sejam os principais sistemas regionais, ainda existem o sistema Árabe e o sistema Asiático, um proveniente da adoção da Carta Árabe de direitos humanos em 1994 e outro da Carta Asiática de Direitos Humanos em 1997, respectivamente (OLIVEIRA, 2013, p. 103-104).

Como já observado, houve, e ainda há, grande resistência dos Estados quanto à adesão de tratados que versem sobre os DESCS, com a clássica argumentação de que estes implicariam deveres positivos do Estado, e assim, encontram diversas limitações, entre as mais citadas está a escassez de recursos (BACELLAR FILHO, 2014, p. 253). ${ }^{4}$

A concepção contemporânea de direitos humanos já comprova que esse discurso se encontra ultrapassado, tendo em vista o caráter negativo e positivo dos direitos humanos de qualquer espécie ou geração, isto é, dos direitos individuais e políticos aos sociais, culturais e econômicos.

É preciso destacar que os direitos fundamentais implicam obrigações de fazer, de abstenção e de respeito. Assim, não existem "direitos gratuitos e direitos caros", pois para sua concretização todos têm custo e necessitam de proteção por parte do Estado, o que explica a indivisibilidade e a interdependência dos direitos, em que um mesmo direito contém "pretensões híbridas" que se caracterizam por sua multifuncionalidade (CARBONELL, 2015, p. 47).

Há, assim, direitos sociais com conteúdo dos direitos de liberdades para a proteção de bens jurídicos e vice-versa. $\bigcirc$ exemplo mais citado pela doutrina é a liberdade sindical, direito inerente ao trabalhador e muito caro a este artigo, em decorrência dos casos escolhidos para serem analisados.

Em resumo, nas palavras de Alexy (2014, p. 249), um "direito fundamental completo é um feixe de posições de direitos fundamentais", com as funções de proteção e prestação, que resultam em obrigações ao Poder Público e pretensões aos particulares. A prestação divide-se em fática e normativa, sendo esta última de proteção e função de organização e procedimento (ALEXY, 2014, p. 196-203; HACHEM, 2014, p. 130).

Afirmando esse posicionamento, Proner (2007, p. 24-25) aduz que tanto os DESCS quanto os direitos individuais são dotados de obrigação de fazer e não fazer "conexas e complementares", havendo, assim, um "complexo de obrigações positivas e negativas", e salienta que em muitos casos o Estado está obrigado a regulamentar ou criar mecanismos organizacionais para que haja verdadeiro

\footnotetext{
4 Tendo em vista a brevidade do artigo não há como tratar especificamente da reserva do possível, tema amplamente discutido quando o foco são os direitos sociais, porém, cita-se sensível posicionamento do professor Bacellar Filho (2014, p. 253) para quem: Milhões de reais são destinados à publicidade estatal e promoção pessoal dos governantes, "[...] inúteis e caríssimos projetos que - em afronta à inteligência da sociedade [...] dividendos políticos e retribuição de promessas eleitoreiras", enquanto hospitais se encontram em condições de calamidade, sem estrutura e medicamentos. Portanto, é preciso cobrar dos eleitos "cada vez com maior intensidade e substância uma atuação que combine com os discursos proferidos nos palanques eleitorais."
} 
exercício do direito, como, por exemplo, no caso de livre associação a sindicatos ou restrições e obrigações a terceiros, como nas relações trabalhistas.

No entanto, salvo no sistema regional Africano, os DESCS foram tardiamente reconhecidos em documentos oficiais, encontrando grandes dificuldades de efetivação. São necessárias estratégias como a interpretação dinâmica e evolutiva (as Convenções como living instruments) para sua proteção, o que destoa do discurso de indivisibilidade e interdependência defendido tanto pela Declaração de Direitos Humanos quanto pela doutrina.

Como se não bastassem todos os problemas quanto à sua efetivação, os direitos sociais apresentam mais uma dificuldade, parte da doutrina defende a impossibilidade da justiciabilidade desses direitos, o que é facilmente rebatido pela característica multidimensional dos direitos fundamentais, sobretudo sobre sua interdependência.

Nesse aspecto, imprescindível mencionar os ensinamentos de Hachem (2013, p. 85): Quanto às pretensões jurídicas, a diferenciação entre direito fundamental em sentido amplo e em sentido estrito: (i) Sentido amplo - "conjunto de pretensões jurídicas"; (ii) Sentido Estrito- "cada pretensão jurídica isoladamente pode ser chamada de direito fundamental." Quanto à titularidade, que pode ser objetiva ou subjetiva: (i) Subjetiva - implica a titularidade (individual ou transindividual) de exigir administrativamente ou judicialmente uma prestação positiva ou negativa do Estado para ver seu direito garantido; (ii) Objetiva - consiste na obrigação dos Estados de tomarem medidas de promoção e proteção dos direitos fundamentais, independentemente "do vínculo subjetivo jurídico do cidadão." (HACHEM, 2013, p. 643-647).

Significa dizer que todos os direitos fundamentais são dotados de dupla titularidade e dupla dimensão, pois cada um contém um conjunto de prestações jurídicas que pode ser exigido individualmente, em decorrência da dimensão objetiva, e coletivamente, em face da dimensão objetiva.

Os trabalhadores são grandes responsáveis pelo surgimento dos direitos sociais, por meio de lutas e reivindicações que objetivavam a criação de um "conjunto de direitos que projetam os trabalhadores e suas famílias", tornando-os verdadeiros sujeitos de direitos (CARBONEL, 2015, p. 40), vez que se encontravam dentro de um contexto de ausência de garantias e proteção à classe trabalhadora.

Em análise mais aprofundada observa-se que os direitos sociais dos trabalhadores são mecanismos de desenvolvimento do capitalismo, em que o Estado cede "os anéis para não perder os dedos", dando origem ao direito capitalista do trabalho, assim denominado por Ramos Filho (2012, p. 48). Mas não há como negar que a concessão de direitos a essa classe foi um avanço.

Em que pese tenham sido protagonistas na conquista dos direitos sociais, os trabalhadores são os primeiros a ter seus direitos cerceados, notadamente em tempo de crise, por meio da flexibilização e da desregulamentação (RAMOS FILHO, 2012, p. 49), em governos autoritários, em que líderes e sindicalistas são alvo de perseguições, e pela existência de trabalho escravo. 
O direito social ao trabalho, os direitos individuais e coletivos dos trabalhadores, assim como os direitos de liberdades de indivíduos trabalhadores atingem uma camada numerosa da população dos continentes, pertencentes, via de regra, a um grupo vulnerável, mas detentor de tutela tanto no sistema global quanto nos sistemas regionais, consagrados pelos três sistemas, ora estudados, cada um em documento específico (CONVENÇÃO AMERICANA DE DIREITOS HUMANOS, 1969; CONVENÇÃO PARA PROTEÇÃO DO HOMEM, 1950; COMISSÃO AFRICANA DOS DIREITOS HUMANOS E DOS POVOS, 1981).

Portanto, não raramente as Comissões e Cortes se veem frente a decisões que versem sobre tais direitos. Passa-se, assim, a discorrer sobre casos analisados pelos três sistemas estudados neste trabalho, a fim de verificar o alcance da proteção jurisdicional, especialmente no que tange à proteção dos direitos sociais, ainda tão mitigados e esquecidos.

\section{Sistemas regionais e casos de violações contra direitos dos trabalhadores}

Cabe esclarecer que serão analisados casos em que trabalhadores foram alvo de violações, entretanto muitos deles são classificados pelos sistemas como casos de direitos políticos e individuais, e outros classificados como de direitos sociais e econômicos. Porém, é importante frisar que se defende com fundamentos na concepção contemporânea de direitos humanos, bem como na multifuncionalidade dos direitos fundamentais, eis que não há uma divisão estanque entre tais direitos, ao contrário, há uma relação de interdependência.

Inclusive, existem justificativas para que os denunciantes aleguem violação de direitos individuais, tendo em vista ainda a grande resistência dos países quanto à proteção dos direitos sociais. Isso se reflete, por exemplo, no fato de que no sistema europeu apenas as decisões de direito individual é que são vinculantes, ao passo que as de direitos sociais econômicos e culturais não.

A resistência quanto aos direitos sociais se expressa também no pequeno número de países que aderem aos protocolos que versam sobre tais temas, por tudo que já foi exposto em item supra.

Por opção metodológica as decisões escolhidas versam sobre quatro temas centrais: (i) casos envolvendo questões sindicais, de associação e de greve; (ii) casos envolvendo direitos concernentes a verbas trabalhistas, bonificações e aposentadorias; (iii) casos envolvendo assassinato de trabalhadores; (iv) e casos envolvendo trabalho escravo ou condições inadequadas de trabalho.

Foram selecionados casos das três cortes. Porém, foi conferida especial atenção aos casos da Corte Interamericana, sobretudo casos brasileiros. Ainda, cabe realizar mais uma ressalva quanto aos casos brasileiros, posto que vários envolvem trabalhadores do Movimento Sem Terra (MST).

Em relação à Corte Europeia, os casos selecionados foram escolhidos com base na palestra proferida na Escola Nacional de Formação e Aperfeiçoamento de Magistrados do Trabalho 
(Enamat), em 20 de agosto de 2014. E por fim, tendo em vista a recente criação do sistema Africano, em particular a Corte Africana, houve imensa dificuldade na busca de jurisprudência; assim, serão apresentados casos julgados pertinentes ao tema, mas que, infelizmente, não são suficientes para contemplar as classificações metodologicamente adotadas.

\subsection{Casos da Corte Interamericana de Direitos Humanos}

O primeiro litígio em que a Corte Interamericana classificou como de DESCS foi justamente sobre direitos dos trabalhadores no caso Baena Ricardo e outros Vs. Panamá, (PRONER, 2007, p. 23), em que 270 servidores públicos foram despedidos de maneira arbitraria, após participarem de manifestação que tinha como bandeira de luta o reajuste salarial. Esses trabalhadores foram acusados injustificadamente de conivência com suposto golpe militar (Caso Baena Vs. Panamá, 2001).

O Estado foi condenado a adimplir as dívidas trabalhistas, bem como a indenizar a título de dano moral, tendo ainda a obrigação de reintegrar os trabalhadores, com fundamento nos princípios da legalidade, irretroatividade, garantia e proteção judicial e liberdade sindical (PRONER, 2007, p. 23). Foi a primeira vez que a Corte aplicou tanto o Pacto San Jose da Costa Rica quanto o Protocolo adicional de San Salvador. Isso porque reconheceu que o direito à liberdade sindical é inerente ao direito humano do trabalhador e, se houve ratificação do protocolo por parte do Estado, este tem o dever de respeitar tal direito (LONG, 2009, p. 82).

O caso dos trabalhadores demitidos do congresso vs. Peru, no qual trabalhadores também foram demitidos por exercerem seus direito de liberdade, teve especial contribuição no que tange à afirmação e especificação do controle de convencionalidade interno na América, que havia sido formalizado pela primeira vez no caso Almonacid Arellano e outros vs. Chile - quando o termo "controle de convencionalidade" foi citado pela primeira vez pela corte em 2006 em sede de voto proferido pelo juiz Sergio Garcia Ramirez (MAZZUOLI, 2013, p. 96-97).

De forma sintética, no caso dos trabalhadores ficou estabelecido que incumbe aos magistrados dos países, para além da análise do controle de constitucionalidade, o controle de convencionalidade, isto é, em verdadeiro controle difuso de convencionalidade (MAZZUOLI, 2013, p. 96-98).

No caso Acevedo Buendia Vs. Peru a Corte Interamericana reconheceu o direito de 273 trabalhadores, integrantes da Associação de Demitidos e aposentados da Controladoria Geral da República, que pleiteavam o cumprimento das sentenças judiciais do Tribunal Constitucional do Peru, que lhes atribuiu o direito ao recebimento das mesmas verbas remuneratórias, gratificações e bonificações que os trabalhadores em exercício, desde que fossem cargos idênticos, similares ou equivalentes. O Estado do Peru foi condenado ao reembolso dos valores, dano moral, com fundamentos no direito à proteção judicial, direito à propriedade privada e obrigação de respeitar 
os direitos (JURISPRUDÊNCIA DA CORTE INTERAMERICANA DE DIREITOS HUMANOS, 2014, p. 275).

Mais uma vez o Peru foi condenado pela violação a direito de trabalhadores em caso denominado Cinco Aposentados Vs. Peru. Este aborda direito dos aposentados que durante anos exerceram o direito a determinado regime previdenciário, depois modificado. $\bigcirc$ tribunal do Peru se pronunciou no sentido de que os trabalhadores deveriam usufruir de regime de aposentadoria de acordo com a legislação vigente à época de sua concessão. Entretanto, essa decisão não foi cumprida pelo Estado, sendo o caso levado à Corte. Com base no direito à propriedade privada, na proteção judicial, no descumprimento das obrigações gerais, a Corte condenou o Estado a tomar providências, bem como reembolsar e reparar os danos materiais sofridos pelos aposentados, assim como os imateriais (JURISPRUDÊNCIA DA CORTE INTERAMERICANA DE DIREITOS HUMANOS, 2014, p. 7).

Em 1999 o Brasil foi condenado pela Corte Interamericana no caso Escher e outros Vs. Brasil, por interceptação telefônica ilegal em face de membros do Movimento de Trabalhadores sem Terra (MST), no Paraná. Dessa forma, o Estado foi compelido a indenizar vítimas pelo dano moral sofrido e dar seguimento à investigação para se auferirem os fatos, tudo com base nos argumentos de garantias e proteções judiciais (CORTE INTERAMERICANA DE DIREITOS HUMANOS, 2009).

Outro caso envolvendo integrantes do MST é o Garibaldi vs. Brasil, em que o trabalhador Sétimo Garibaldi foi assassinado no momento em que proprietários tentavam realizar a desocupação de terras. Com fundamento nas obrigações gerais, garantias e proteções judiciais, o Estado brasileiro foi condenado ao pagamento de indenização à família do trabalhador Sétimo Garibaldi e obrigado a tomar medidas cabíveis contra os servidores responsáveis por eventuais falhas que obstaculizaram a investigação, bem como dar seguimento adequado ao Inquérito Policial, para punição dos criminosos, com os mesmos fundamentos do caso Escher, aliado ao direito a vida (CORTE INTERAMERICANA DE DIREITOS HUMANOS, 2009).

O caso conhecido como Corumbiara é mais um triste retrato de violências sofridas por integrantes do MST, em que a polícia usou de abuso de poder, com emprego de violência e tortura, para cumprir decisão judicial que determinava a saída dos trabalhadores rurais que haviam invadido a fazenda Santa Elina, o que resultou em 10 mortes e diversos feridos. O Brasil foi condenado com fundamento na violação ao direito à vida, integridade pessoal, proteção e garantias judiciais, bem como obrigações gerais. Além de todas as recomendações impostas nos casos já apresentados, foi recomendado que o país alterasse o artigo $9^{\circ}$ do Código Penal Militar e 82 do Código de Procedimento Penal, a fim de que a competência para investigação de crimes que violem direitos humanos fosse delegada à polícia civil (TOJO; LIMA, 2004). Caso muito semelhante ficou internacionalmente conhecido como Massacre dos Carajás, em que houve 19 mortes de integrantes do MST (SILVEIRA FILHO, 2015). 
Todavia, o assassinato de trabalhadores não é um problema isolado do Estado brasileiro. Para tanto, pode-se citar o caso Huilca Tecse vs. Peru, em que o trabalhador que ocupava o cargo de secretário geral da Confederação Geral dos Trabalhadores do Peru, foi executado por membros do grupo Colina, vinculado ao governo Peruano. O Peru realizou acordo e comprometeu-se a investigar e sancionar os culpados, reconhecer sua responsabilidade, pedir desculpas em ato público, realizar homenagens ao trabalhador e reparar moralmente e materialmente os familiares (CORTE INTERAMERICANA DE DIREITOS HUMANOS, 2005).

Qualquer tipo de violação de direitos, sobretudo morte de trabalhadores e impunidade, causam revolta em toda sociedade, mas um problema gravíssimo, mas ainda recorrente na América é o trabalho escravo e as condições de trabalhos degradantes, como será a seguir apreciado. ${ }^{5}$

Um caso de extrema gravidade e que representa um marco foi o caso José Pereira vs. Brasil. Em 1989 cerca de 60 trabalhadores estavam em situação de trabalho escravo na fazenda Espírito Santo; ao tentar fugir, José Pereira foi gravemente ferido, o que the ocasionou lesões permanentes (CORTE INTERAMERICANA DE DIREITOS HUMANOS, 2003). O caso foi levado à Comissão Interamericana de Direitos Humanos como apenas um dos vários casos de trabalho escravo existentes no Brasil à época, mas esse foi o primeiro caso em que o Brasil realizou acordo de solução amistosa, reconhecendo sua responsabilidade internacional, assumindo, assim, compromissos como indenizações, implementações de medidas preventivas, fiscalizatórias e sancionatórias, de acordo com a Convenção Americana (TOJO; LIMA, 2004).

O caso Fazenda Brasil Verde é mais um retrato da escravidão o Brasil, em que trabalhadores foram mantidos como escravos durante 11 anos, e dois deles desapareceram. O Estado foi condenado ao pagamento de indenização material e moral, prosseguimento de investigação adequada e imparcial, medidas sancionatórias, fiscalizatórias, e mecanismos que permitam a localização das vítimas de trabalho escravo e de suas famílias para que sejam devidamente indenizados (ORGANIZAÇÃO DOS ESTADOS AMERICANOS, 2011).

Ainda, destaca-se o desafio do fortalecimento e ampliação de políticas públicas e legislação contra o trabalho escravo, inclusive de aproximação entre a jurisdição penal e trabalhista, e averiguação dos servidores que não agiram com o devido zelo na investigação, permitindo a impunidade e correspondente aplicação de sanção. Nessa direção, o Brasil foi condenado em 2011 com base em diversos dispositivos da Convenção Americana, entre eles: integridade pessoal, proibição da escravidão, garantias e proteção judicial, liberdade de circulação e obrigações gerais (ORGANIZAÇÃO DOS ESTADOS AMERICANOS, 2011).

\footnotetext{
5 Observa-se que, embora o grande marco da inclusão do direito ao trabalho e dos trabalhadores seja o protocolo de San Salvador, desde o Pacto de San José da Costa Rica já havia disposição sobre o trabalho escravo, em seu artigo 6 e incisos, e várias decisões sobre trabalhadores que estavam submetidos a condições degradantes de trabalho, tema que só foi tratado no protocolo adicional.
} 


\subsection{Casos da Corte Europeia de Direitos Humanos}

Transita-se agora para a análise de casos envolvendo a violação de direitos dos trabalhadores do sistema europeu. No litigio Gacia Mateos vs Espanha, figura como vítima a Sra. Garcia que, com base em disposições da legislação espanhola, pediu para o empregador a diminuição da jornada laboral, para cuidar de seu filho com menos de seis anos de idade. $O$ pedido foi recusado pelo empregador, motivo pelo qual a trabalhadora foi obrigada a adentrar com demanda judicial que restou infrutífera em todas as instâncias (CORTE EUROPEIA DE DIREITOS HUMANOS, 2009).

Em 2007 a corte julgou o caso atribuindo direito à trabalhadora, tendo em vista o desrespeito a diversos princípios, sobretudo da não discriminação de gênero, vez que a negativa ao pedido impossibilitou que esta conciliasse sua vida profissional e suas obrigações como mãe, assim como violação ao artigo 14 da Convenção Europeia, que versa sobre a proibição de discriminação. Acontece que o Estado não conseguiu cumprir sua própria legislação, portanto foi condenado ao pagamento de indenização a título de dano moral (STRAPAZZON; BELLINETTI; COUTINHO, 2015) .

No Caso Demir e Bayakara vs Turquia a discussão principal é sobre o direito de greve dos servidores públicos. Em 2008, um acordo coletivo realizado entre sindicato e governo foi declarado nulo pelo próprio governo, por se tratar de acordo realizado por sindicado dos servidores públicos. Esse caso representa um marco para a Corte Europeia, pois julgou no sentido de que, embora a Convenção Europeia não trate especificamente do direito de greve, sequer o citando, a interpretação deveria ser à luz dos tratados e convenções do sistema global, que reconhecem expressamente tal direito - a ser reconhecido aos servidores públicos da Turquia (NUSSBERGER, 2014).

Entretanto, a Corte mostrou posicionamento bastante diverso em outros litígios, como no caso Sindicato POA vs Grã-Bretanha, que igualmente versava sobre a possibilidade de servidores públicos exercerem o direito de greve, mais especificamente os servidores que exerciam a função de guardas prisionais. Antes de apresentar denúncia à Corte Europeia, o sindicato havia levado a demanda ao Comitê de Liberdades Sindicais da OIT, que entendeu pela impossibilidade de greve por parte desses servidores. A corte Europeia decidiu por sua incompetência, vez que outro órgão internacional já havia tratado do caso (NUSSBERGER, 2014).

Mais uma demanda envolvendo a Grã-Bretanha, sindicatos e o direito de greve ocorreu pela proibição do direito de solidariedade à greve, ou seja, quando trabalhadores de uma empresa entram em greve por solidariedade a outra. Nesse caso, a corte foi na contramão do esperado e afirmou que, mesmo sendo um direito internacionalmente reconhecido, era preciso analisar a realidade socioeconômica daquele momento. Embora o direito de greve seja corolário do direito à liberdade de associação e indispensável para sua concretização, a solidariedade à greve não tem essa mesma característica, por isso sua proibição não fere a Convenção Europeia (NUSSBERGER, 2014).

Outro caso muito interessante decidido pela Corte Europeia - Padres vs Romenia - envolveu padres que constituíram um sindicato, vetado pela igreja, com fundamento em uma supos- 
ta proibição ou impossibilidade de existência de instituições compostas por integrantes da própria igreja que venham a questionar sua autoridade. Nesse litígio havia inúmeros interesses e direitos a serem observados, liberdade de associação, liberdade sindical, direito dos padres, mas também havia toda uma questão de autonomia e dogma da igreja que se caracteriza na liberdade religiosa. Por nove a oito ficou estabelecido pela Corte que a criação do sindicato era permitida pela legislação, ao passo que nada era estabelecido quanto ao poder de veto da igreja (NUSSBERGER, 2014; CORTE EUROPEIA DE DIREITOS HUMANOS, 2013).

Poucos casos referentes a trabalho escravo foram levados à Corte Europeia de Direitos Humanos (NUSSBERGER, 2014). Destaca-se o caso Siliadin vs França, em que uma trabalhadora Africana foi explorada, sofrendo ameaças com jornada de trabalho descomunal e retirada de seu passaporte. Contudo, mesmo com tantas violações, a trabalhadora ganhou apenas uma compensação pecuniária. Os fatos foram julgados pela Corte, que obrigou a França a realizar alterações legislativas, a fim de que criasse mecanismos de punição e devida compensação (CORTE EUROPEIA DE DIREITOS HUMANOS, 2013). ${ }^{6}$

Também acerca de trabalho escravo mencione-se o caso Kawogo vs Reino Unido. Nesse caso, a corte recebeu denúncias de uma africana que residia no Reino Unido de forma ilegal (anteriormente teve autorização para trabalho doméstico) e trabalhava para um casal de idosos, sem salário, em jornadas laborais extenuantes, condições inadequadas de trabalho e higiene, e, ainda, teve seu passaporte retido. Além disso, foi hospitalizada com quadro de psicose e diagnosticada como portadora do vírus HIV. A trabalhadora realizou pedido de asilo que não foi concedido, concluído, pois, que não havia indícios de tráfico de pessoas, e sim uma disputa entre a trabalhadora e seu primo que não lhe repassava a totalidade de seu salário (GRUPO DE ESTUDOS DE DIREITOS HUMANOS, 2017).

A corte decidiu que as investigações foram insuficientes, eis que se averiguou tão-somente o crime de tráfico de pessoas. Em que pesem evidentes indícios de servidão doméstica, o Estado francês não adotou medidas suficientemente eficazes para punição dos culpados, portanto, foram desrespeitados preceitos da Convenção quanto à proibição de trabalho escravo, direito e respeito à vida, direito a recursos efetivos, bem como ficou demonstrada omissão legislativa por parte do Estado - motivos que levaram sua condenação para fins de indenização à trabalhadora (STRAPAZZON; BELLINETTI; COUTINHO, 2015, p. 227).

Sendo o mais antigo sistema, é natural que todos os demais sistemas se espelhem na Corte Europeia, que possui arsenal jurisprudencial bastante rico. Mas é importante destacar que a Europa possui outro contexto histórico de desenvolvimento e de implementação do sistema de proteção de direitos humanos, sendo assim, casos de violação que são comuns à Corte Interamericana - como

\footnotetext{
$\overline{6}$ Sobre esse caso ver Scott (2013, p. 129-137).
} 
violações inerentes a governos autoritários e desaparecimentos - passaram a ser familiares ao sistema Europeu após o ingresso de países do Leste Europeu ao sistema.

Desse modo, surgem novos temas de discussão com a inclusão desses países ao sistema Europeu. A Corte tem cada vez mais recorrido à jurisprudência do sistema Interamericano. Como demonstra o relatório produzido pelo Conselho da Europa, ao analisar 25 sentenças proferidas pela Corte Europeia, há expressiva referência à jurisprudência da Corte Interamericana. Também foram localizados julgados da Corte Europeia concernentes a direitos sociais, com menção às sentenças da Corte Interamericana nos casos Acevedo Buendia vs. Peru e Cinco Pensionistas vs. Peru (PIOVESAN, 2014, p. 90).

Faz-se referência às palavras proferidas pela juíza Angelika Nussberger quanto aos casos de direito do trabalho levados até o sistema Europeu de Proteção de Direitos Humanos, pois:

[...] tudo começou com uma espécie de surpresa. A Corte Europeia de Direitos Humanos não foi criada para ser importante nos assuntos do Direito do Trabalho, mas, agora, sessenta anos depois da Consciência Europeia, já decidiu muitos casos de Direito do Trabalho e todas as Cortes de Trabalho europeias seguem a nossa jurisprudência e se interessam pelo que fazemos em Strasbourg. (NUSSBERGER, 2014).

Feitas essas considerações sobre a Corte europeia, passa-se à análise da jurisprudência do sistema Africano.

\subsection{Casos da Comissão e da Corte Africana de Direitos Humanos e dos Povos}

Segundo informações extraídas do site da Corte Africana de Direitos Humanos, até o momento, houve atuação dessa corte em: 28 petições relacionadas com matéria contenciosa, cinco pedidos de parecer consultivo e 23 processos concluídos (TRIBUNAL AFRICANO DE DIREITOS HUMANOS E DOS POVOS, 2018).

Conforme já descrito, como a criação do sistema Africano é recente, houve grande dificuldade na busca jurisprudencial. Portanto, foram selecionados alguns casos que, ao menos indiretamente, tratam de direitos de trabalhadores, até porque, como se defende, os direitos humanos são interdependentes.

Os casos aqui trazidos datam tanto do período anterior à instituição do Tribunal Africano, quanto do posterior, sendo contenciosos e consultivos, com o objetivo de contribuir mesmo que minimamente para os estudos de casos desse sistema, que se mostra inicial, mas também carente de maiores atenções.

No caso Dabalorivhuwa Patriotic vs República da África do Sul, alegou-se violação aos direitos trabalhistas e de povo indígena. Foi instituído fundo de pensão e aposentadoria, que beneficiava inúmeros servidores públicos. Porém, após golpe militar, um conselho assume seu controle e determina, por meio de legislação específica, que os membros ativos, assim que alcançassem 
determinado valor de acumulação, seriam obrigados a transferir o dinheiro para uma instituição privada - por meio de verdadeira privatização que causou grande prejuízo às vítimas. A Comissão entendeu pela inadimissibilidade da petição, pois os fatos ocorreram em momento que a Carta não era aplicável à República da África do Sul, bem como não teria havido cumprimento por parte dos denunciantes das exigências estabelecidas para proprositura da demanda (TRIBUNAL AFRICANO DE DIREITOS HUMANOS E DOS POVOS, 2006).

No caso Convenção Nacional de Professores de Sindicatos vs. República do Gabão, em 03 de agosto de 2011, professores, líderes sindicais da Convenção Nacional de Professores de Sindicatos da República do Gabão, adentraram com demanada que tramitou no Tribunal Africano em razão das violações dos direitos sindicais consagrado na Carta Africana dos Direitos Humanos e dos Povos. Entretanto, por unanimidade, o Tribunal Africano decidiu nos termos dos artigos $5^{\circ}$ e 34 do Protocolo, por sua incompetência para receber o pedido apresentado contra a República do Gabão (TRIBUNAL AFRICANO DE DIREITOS HUMANOS E DOS POVOS, 2011).

Conforme os fatos trazidos ao caso, este do Sr. Esmaila Connateh e outros 13 gambianos é comovente, pois trabalhadores foram deportados da Angola em março, abril e maio de 2004, sendo expulsos e maltratados por conta de suas nacionalidades. Seus documentos oficiais foram retidos, inclusive passaportes, vistos, autorizações de residência e trabalho pela operação denominada Brilhante. Depois foram encaminhados a centros de detenções em diferentes regiões da Angola, como Cafunfu, Kisangili, Saurimo e Launda, em condições desumanas, sem alimentação e condições de higiene. Também houve invasão por parte das Forças Armadas Angolanas em várias aldeias onde as vítimas residiam, seus bens foram confiscados, e não lhes foi proporcionada oportunidade de defesa. Todos os trabalhadores possuíam autorização para trabalhar. Todavia, foram presos pela presunção de que os estrangeiros não foram autorizados a exercer atividades de mineração no país (TRIBUNAL AFRICANO DE DIREITOS HUMANOS E DOS POVOS, 2004).

A recomendação afirmou que "não é a primeira vez em que se revelaram semelhantes violações dos direitos humanos de estrangeiros num contexto de expulsões/deportações em massa pela República de Angola." Portanto, recomendou que a República Angolana coibisse atos discriminatórios, assegurasse condições adequadas a indivíduos que estão em situação prisional, assim como meios de proteção e instauração de procedimento investigativo para punição dos culpados, também, mecanismos de promoção de direitos humanos e encaminhamento de relatórios para que o Estado demonstre e comprove o cumprimento das recomendações (TRIBUNAL AFRICANO DE DIREITOS HUMANOS E DOS POVOS, 2004).

No caso Jean Vs República Democrática do Congo (RDC), discutiu-se a situação fática vivida pelo trabalhador que, em 1974, obteve o estatuto de refugiado político concedido e reconhecido pela República do Zaire e pela Comissão das Nações Unidas. Posteriomente formou-se como engenheiro e foi contratado pela empresa Onatra. Em 1996, após a guerra entre a RDC e Burundi, Uganda e Ruanda, no Leste do país, o Parlamento de Transição aprovou a Resolução n. 
04 / HCR6PT / 96, que permitiu a rescisão contratual de trabalhadores refugiados, sem quaisquer pagamentos de verbas trabalhistas. $O$ trabalhador adentrou com inúmeros mecanismos jurídicos para reaver seus direitos, mas restaram infrutíferos, especialmente porque foi forçado a deixar RDC em junho de 1997, passando a refugiar-se em Lomé - o que impossibilitou o esgotamento das vias judiciais daquele país. No entanto, a Comissão não acatou os argumentos do trabalhador e, com fundamentos na Carta Africana, declarou a inadimissibilidade da demanda (TRIBUNAL AFRICANO DE DIREITOS HUMANOS E DOS POVOS, 2002).

Adicione-se mais um caso envolvendo direitos trabalhista, em que o trabalhador contratado pela embaixada de Gana em Conakry, Guiné, como tradutor, foi demitido em decorrência de relatório elaborado pelas autoridades guineenses, no qual era acusado de articulador do ataque contra o Ganês Chancelaria e os escritórios Ghana Airways em Conakry, sem qualquer direito de defesa. Entretanto, mais uma vez, a corte declara a petição inadmissível, tendo em vista a falta de esgotamento dos recursos internos (TRIBUNAL AFRICANO DE DIREITOS HUMANOS E DOS POVOS, 1998).

Por fim, cabe menção ao caso União Nacional dos Sindicatos Autônomos do Senegal vs Senegal, envolvendo prisão do líder sindical Mademba Meia e de mais 25 dirigentes, que foram mantidos durante quatro dias presos, sem que lhes fosse permitida comunicação com advogados ou familiares. De forma semelhante aos demais casos descritos, a Comissão entendeu que estavam diante de inúmeras violações da Carta Africana, mas os recursos internos não teriam sido esgotados, conforme dispõe o artigo 56 da Convenção (TRIBUNAL AFRICANO DE DIREITOS HUMANOS E DOS POVOS, 1999).

Os casos destacados suscitam instigante análise, sobretudo quanto à indivisibilidade e interdependência dos direitos humanos, com base também nos fundamentos teóricos mencionados em tópico anterior, em relação à multifuncionalidade dos direitos fundamentais, dupla titularidade e a necessidade de uma visão menos simplista e estanque dos direitos.

\section{Análise dos casos}

É evidente que nas decisões analisadas existem violações a direitos sociais e individuais, na mesma medida. Mas é ainda mais nítida a preferência dos sistemas regionais em motivar suas decisões com fundamentos em direitos individuais, conseguindo justificar decisões que versam sobre verbas e benefícios trabalhistas pelo direito de propriedade, um dos direitos mais clássicos dos ditos direitos de primeira geração.

Nos casos de Baena Ricardo e trabalhadores demitidos do congresso, ambos classificados pela Corte Interamericana como de direitos sociais, por se tratarem de trabalhadores despedidos arbitrariamente, apenas por terem exercido direito de greve, a corte fundamentou a sentença eminentemente em direitos individuais. Isto é, mesmo a corte afirmando que o objeto central do caso 
é o direito social, admite a existência de inúmeras violações de direitos individuais, mais que isso, os fundamentos das sentenças são preponderantemente de direitos individuais. $\bigcirc$ mesmo acontece no caso "os cinco pensionistas", classificado como caso de DESCS - porém toda a fundamentação que culminou na condenação do Estado se baseou no direito de propriedade privada.

Os conceitos e teorias defendidos no presente trabalho são corroborados nos tantos casos do sistema Interamericano, com ênfase em casos em que líder sindical teve seus direitos cerceados, sofrendo prejuízos de elevada monta sem correspondente compensação e adequada punição dos violadores. Está-se frente a graves violações de direitos individuais; do mesmo modo, está-se diante de práticas responsáveis por diversas violações de direitos sociais. Tem-se como exemplo o direito sindical, objeto de proteção de todos os sistemas.

No caso Hulca vs. Peru, houve acordo, mas merece destaque importante fundamentação por parte da Corte Interamericana, que ampliou o entendimento antes disposto, de modo a discorrer sobre a dupla dimensão do direito de liberdade de associação: coletiva e individual. E reafirmando entendimentos lançados na decisão do caso Cantoral Humany y Garcia Sata Cruz vs. Peru, defendeu que "los derechos sindicales no pueden ser ejercidos en um contexto de impunidad frente a situaciones de violencia sindical caracterizadas, inter alia, por ejecuciones extrajudiciales." (TRIBUNAL AFRICANO DE DIREITOS HUMANOS E DOS POVOS, 1999).

Casos inerentes ao direito do trabalho são os mais citados para demonstração da multifuncionalidade e dupla dimensão. Em relação à jurisprudência da Corte Interamericana, o número de demandas envolvendo grupos sociais e sindicatos é reveladora da dupla titularidade dos direitos.

Os numerosos casos envolvendo atos de violência pela polícia brasileira demonstram que mesmo após o regime militar o país não conseguiu romper em absoluto com as práticas autoritárias de regime repressivo militar, revelando, assim, marcas de um continuísmo autoritário." (PIOVESAN, 2011, p. 404).

Dentro dessa mesma lógica, ousa-se afirmar que os casos julgados pela Corte envolvendo trabalho escravo, em que indivíduos foram submetidos a condições sobre-humanas de trabalho e que demonstram indícios de centenas de indivíduos na mesma condição, retratam que, embora a abolição da escravidão tenha ocorrido há séculos, o trabalho escravo tipificado como crime e a existência de políticas adotadas contra essa prática, ainda remanesce o desafio de sua plena implementação.

Porém, esse não é um problema isolado do sistema regional interamericano, visto que a jurisprudência do sistema Europeu demonstra que existem trabalhadores nessa condição, e mais, que os países Europeus permitiram que tais crimes ficassem impunes, com argumentos completamente infundados.

No caso Kawogo vs Reino Unido, em que o Estado entendeu que como não havia indícios de tráfico de pessoas, mesmo estando evidente a situação de servidão doméstica, os tribunais e a polícia não enfrentaram o caso, sob o argumento de que o país não possuía legislação especifica. 
Nos dois casos de trabalho escravo analisados, ambas as trabalhadoras submetidas a essa condição eram africanas. E repita-se: os crimes foram acobertados pelos seus Estados. No caso Siladin vs França houve a condenação em prol da criação de mecanismos mais eficazes de punição e alteração legislativa.

Por meio de estudo de casos, observa-se que o contexto da Europa fazia com que a Corte decidisse sobre casos menos violentos, nos quais os objetos principais de discussão versavam sobre direitos trabalhistas concernentes a verbas e direito de greve. Tal conjuntura passa a ser modificada com a inclusão dos países do Leste Europeu ao sistema, que apresentam violações típicas de governos autoritários. Conforme descrito, o Tribunal tem se espelhado na jurisprudência da Corte Interamericana, e, por essa razão, optou-se em não tratá-los, uma vez que, a partir dessa informação, pode-se saber a linha seguida, sobretudo quanto aos direitos sociais.

O direito de greve dos servidores públicos é um tema bastante encontrado na Corte Europeia, assim, citaram-se dois casos em que esta aderiu a entendimentos completamente diversos. No caso Demir e Bayakara vs Turquia defendeu a visão contemporânea dos direitos humanos (obrigações positivas e negativas), com fundamentos nos documentos do sistema global. Já no caso POA vs Grã-Bretanha alegou incompetência, justamente porque o caso já havia sido levado a uma agência especializada do sistema global.

Angelika Nussberget, ao tratar do direito de greve dos servidores, relata que o Brasil possui entendimento muito mais evoluído que os países Europeus, tanto que inclui esse direito em seu ordenamento domésticos com hierarquia constitucional. Sabe-se que essa afirmativa não corresponde à realidade, especialmente quanto aos servidores públicos, uma vez que há mais de 25 anos o Estado brasileiro encontra-se omisso na regulamentação desse direito, o que impossibilita seu livre exercício.

Todavia, casos muito interessantes ligados ao direito de greve e sindicatos são observados nesse sistema, como se vê nos litígios POA vs Grã-Bretanha e Padres vs Romenia - o primeiro sobre o direito de solidariedade à greve e o segundo sobre a possibilidade de o bispo vetar sindicatos criados pelos religiosos. No primeiro caso a corte não entendeu que este seria um direito humano fundamental, e no segundo considerou que a legislação do país nada tratava sobre a possibilidade de veto, portanto a igreja não poderia realizá-lo. Esse caso versa sobre inúmeros direitos individuais, mas também coletivos, o que demonstra exatamente a ideia de multifuncionalidade e dupla dimensão.

Ainda sobre a Corte Europeia cita-se o caso Garcia Mateos vs Espanha, em que a Corte julgou o caso de violação a direitos trabalhistas de uma mulher, mais especificamente uma legislação protetiva que visa a possibilitar a inserção da mulher no mercado de trabalho com fundamento na não discriminação.

Mas é preciso lembrar que, após tantos anos de existência, passando-se pela antiga e a nova corte, com tantos casos esse sistema tem ainda que se valer de argumentos como a inter- 
pretação dinâmica e evolutiva pautada na Convenção como living instrument para proteção dos direitos sociais, vez que apenas as decisões que tratam sobre direitos individuais são vinculativas, o que demonstra completa dissonância com o sistema Africano.

Quanto ao sistema Africano, como já foi externado em outras oportunidades, houve grandes dificuldades na procura na sua jurisprudência, por tudo já exposto. Dessa maneira, optou-se por citar todos os casos encontrados que versam mesmo que indiretamente sobre os direitos dos trabalhadores. Duas questões impressionam na análise de casos desse sistema: a quantidade de vezes em que sequer adentrou no mérito do caso, com argumentos processuais; e a violação de direitos em face de trabalhadores estrangeiros.

Como se não bastasse o pequeno número de casos, observa-se uma postura demasiadamente processualista do sistema, o que impossibilita a discussão com relação a posicionamentos adotados. Entre os seis casos averiguados, em cinco houve alegação neste sentido, em um apenas houve julgamento pelo Tribunal que determinou que fossem coibidos atos discriminatórios contra estrangeiros que, mesmo vivendo dentro da legalidade e com autorização para o trabalho, sofrem demissões discriminatórias, cerceados de defesa, sendo deportados e expostos a condições desumanas, simplesmente por sua nacionalidade.

Há, portanto, no sistema Africano uma contradição. De um lado se mostra à frente dos demais, principalmente no reconhecimento dos direitos sociais. Por outro lado, demonstra uma postura ainda muito cautelosa, com fundamentos meramente processuais, como no caso Jean Vs República Democrática do Congo, em que o trabalhador foi obrigado a deixar o país e por motivos óbvios não pode esgotar as vias judiciais. Ou no caso da União Nacional dos Sindicatos Autónomos do Senegal vs Senegal em que mencionam que de fato há diversas violações a direitos, porém alegam o não esgotamentos de recursos.

\section{Conclusão}

1. A concepção contemporânea de direitos humanos nasce com a internacionalização destes, a partir da Declaração Universal de Diretos Humanos de 1948, quando é inaugurado o sistema global de proteção. Os sistemas regionais surgem cada um com um contexto histórico, sendo que o Europeu e o Interamericano protegem primeiramente os direitos individuais, passando a preocupar-se com os sociais, posteriormente. Enquanto o sistema Africano - conhecido por suas inovações - trata de ambos no mesmo documento.

2. Em sendo universais e indivisíveis, os direitos humanos são dotados de interdependência. Todo direito possui uma dimensão positiva e negativa, assim como titularidade individual e transindividual, como um feixe completo de posições, usando-se das palavras de Alexy quando trata dos direitos fundamentais. 
3. Os direitos humanos dos trabalhadores representam nitidamente a multifuncionalidade e dupla titularidade. São objeto de proteção de todas as esferas, geralmente classificados como direitos sociais, porém, mesmo havendo tratativa e preocupação com os direitos sociais num segundo momento pelo sistema Interamericano e Africano, sempre houve menção à proteção do trabalho escravo.

4. Quanto à jurisprudência do sistema Interamericano, considerando a análise de nove casos, verificou-se que a ideia de interdependência dos direitos, multifuncionalidade e dupla titularidade tem sido adotada mesmo que de forma intuitiva, ou pelos fundamentos da interpretação evolutiva. Muitos casos graves de violação contra trabalhadores foram alvo de discussões nesse sistema, desde verbas trabalhistas, demissões pelo exercício de greve até casos de existência de trabalho escravo, mortes de líderes, práticas antissíndicas, violação aos direitos de livre associação. Averiguou-se posicionamento protetivo aos direitos e determinações bastante detalhadas. Dentre os três sistemas observa-se que as fundamentais mais ricas e mais elaboradas são do sistema Interamericano - porém, em um contexto em que há dificuldades quanto ao cumprimento das condenações.

5. Quanto à Corte Europeia, considerando a análise de sete casos, conclui-se que passa por momentos de transição após adoção de países do Leste Europeu ao sistema, com o aumento de demandas nos últimos anos. Observa-se que a ideia de interpretação evolutiva é ainda muito importante a esse sistema, que até agora não rompeu (pelo menos suficientemente) com a figura clássica de dicotomia entre direitos, tanto é que as decisões que são classificadas como de direitos sociais não possuem caráter vinculante - o que demonstra um atraso no posicionamento do mais antigo sistema. Entretanto, a corte tem avançado no sentido de adotar posicionamentos mais amplos, baseando-se nos documentos do sistema global. Verifica-se que os trabalhadores europeus, ainda, possuem extrema dificuldade quanto ao exercício de seus direitos coletivos, sobretudo os servidores públicos. Constatou-se, ainda, que a escravidão é um problema a ser enfrentado e que nos casos investigados os países se mantiveram cúmplices a essas atrocidades.

6. Após numerosas tentativas, foram localizados seis casos do sistema Africano relacionados a direitos dos trabalhadores, desde o nascimento do sistema até a instituição do Tribunal. Entre os seis, apenas um teve análise de mérito e foi realizada pelo Tribunal Africano. Os demais casos - mesmo gravíssimos, conforme externado pelo próprio sistema -, não tiveram a mesma sorte, ao passo que foram considerados inadmissíveis. Após a leitura dos casos, conclui-se que os requisitos meramente formais não foram cumpridos por fatores externos à vontade da vítima, não havendo sensibilidade por parte do sistema a esses fatores e até mesmo certo recuo, diferentemente da postura inovadora que se espera desse sistema. Ainda, dentre os seis casos, três referem-se a desrespeito a trabalhadores estrangeiros; dois versam sobre direitos sindicais, muito semelhantes aos casos da Corte Interamericana; e um sobre verbas. Todos eles inerentes a governos autoritários.

7. Por tudo isso, conclui-se que os sistemas, ainda, não são harmônicos quanto à jurisprudência trabalhista. Os sistemas Interamericano e Europeu, mesmo com realidades e motivos 
diferentes, têm um denominador comum quanto aos direitos sociais: ambos fundamentam suas decisões pelos direitos individuais, usando uma interpretação extensiva. Isso comprova que de fato os direitos não são estanques, possuem multifuncionalidade, dupla titularidade e, acima de tudo, são interdependentes. No sistema Africano, direitos civis e sociais foram contemplados em um mesmo patamar, mas ainda é preciso aguardar uma postura menos formalista do sistema para que conclusões possam ser tomadas. Espera-se que tais sistemas tenham a capacidade de avançar na proteção mais plena e efetiva dos direitos trabalhistas - condição essencial à própria prevalência da dignidade humana.

\section{Referências}

AFRICAN INTERNATIONAL COURTS AND TRIBUNALS. Disponível em: < http://www.aict-ctia.org/ >. Acesso: 20 jan. 2018.

ALEXY, Robert. Teoria dos direitos fundamentais. Tradução Virgílio Afonso da Silva. 2. ed. São Paulo: Malheiros, 2014.

BACELlAR FILHO, Romeu Felipe. Dignidade da Pessoa Humana, Direitos Fundamentais e Direito Administrativo. Revista EurolatinoAmericana de Derecho Administrativo, Santa Fé, v. 1, n. 2, p. 247254, jul./dez. 2014.

BENVENUTO, Jayme; SILVA, Rodrigo Deodato de Souza. Normas e Decisões do Tribunal Europeu e da Corte Interamericana de Direitos Humanos: Aproximações comparativas em matéria de direitos econômicos, sociais e culturais. Revista Latino-Americana de Direitos Humanos, 2011. Disponível em: <http://www.periodicos.ufpa.br/index.php/hendu/article/viewArticle/668>. Acesso em: 22 jan. 2018.

BICUDO, Hélio. Defesa dos direitos humanos: sistemas regionais. Estud. av., São Paulo, v. 17, n. 47, jan./abr. 2003. Disponível em: <http://www.scielo.br/scielo.php?script=sci_arttext\&pid=S0103-40142003000100014>. Acesso em: 22 jan. 2018.

BRANT, Leonardo Nemer; PEREIRA, Luciana Diniz Durães; BARROS, Mariana Andrade. Sistema Africano de Direitos Humanos e dos Povos. 2006. Disponível em: <http://www.dhnet.org.br/direitos/ sip/africa/ua_brant_sistema_africano_leonardo_nemer_caldeira_brant.pdf $>$. Acesso em: 13 jan. 2018.

CARBONELL, Miguel. Los Derechos Sociales: elementos para una lectura em clave normativa. 2010. Disponível: em: < https://archivos.juridicas.unam.mx/www/bjv/libros/8/3980/12.pdf>. Acesso em: 17 ago. 2018.

COMISSÃO DAS COMUNIDADES EUROPEIAS. Carta Comunitária dos Direitos Sociais Fundamentais dos Trabalhadores. Luxemburgo: Serviço das Publicações Oficiais das Comunidades Europeias, 1990. Disponível em: <http://ftp.infoeuropa.eurocid.pt/database/000043001-000044000/000043646.pdf>. Acesso em: 18 jan. 2016. 
COMISIÓN INTERAMERICANA DE DERECHOS HUMANOS. Enlaces de interés. Disponível em: <http://www.oas.org/es/cidh/enlaces/default.asp>. Acesso em: 10 jan. 2018.

COMISSÃO AFRICANA DOS DIREITOS HUMANOS E DOS POVOS. Carta Africana de Direitos Humanos e dos Povos. 1981. Disponível em: < http://www.achpr.org/pt/instruments/achpr/>. Acesso em: 10 jan. 2018.

COMISSÃO INTERAMERICANA DE DIREITOS HUMANOS. Convenção Americana sobre Direitos Humanos. Assinada na Conferência Especializada Interamericana sobre Direitos Humanos, San José, Costa Rica, em 22 de novembro de 1969. Disponível em: < https://www.cidh.oas.org/basicos/portugues/c.convencao_americana.htm>. Acesso em: 10 jan. 2018.

CORTE EUROPEIA DE DIREITOS HUMANOS. Convenção para a Proteção dos Direitos do Homem e das Liberdades Fundamentais. Roma, 04 nov. 1950. Disponível em: <https:/www.echr.coe.int/Documents/Convention_POR.pdf>. Acesso em: 12 jan. 2018.

CORTE EUROPEIA DE DIREITOS HUMANOS. Caso Siliadin Vs França. 2013. Disponível em: $<$ http://ec.europa.eu/anti-trafficking/legislation-and-case-law-case-law/siliadin-v-france-application-no-7331601_en>. Acesso em: 18 jan. 2016.

CORTE EUROPEIA DE DIREITOS HUMANOS. Garcia Mateos v. Spain (2013). Disponível em: < http://hudoc.echr.coe.int/eng?.i=001-116985 > . Acesso em: 12 jan. 2018.

CORTE INTERAMERICANA DE DERECHOS HUMANOS. Disponível em: < http://www.corteidh.or.cr/>. Acesso em: 10 jan. 2018.

CORTE INTERAMERICANA DE DIREITOS HUMANOS. Caso Garibaldis Vs. Brasil. 23 set. 2009. Disponível em: <http://www.corteidh.or.cr/docs/casos/articulos/seriec_203_esp.pdf>. Acesso em: 13 jan. 2018.

CORTE INTERAMERICANA DE DIREITOS HUMANOS. Caso Huilca Tecse Vs. Perú. 03 mar. 2005. Disponível em: <http://www.corteidh.or.cr/docs/casos/articulos/seriec_121_esp.pdf. Acesso em: 17 jan. 2018.

CORTE INTERAMERICANA DE DIREITOS HUMANOS. Caso Baena Vs. Panamá. 02 fev. 2001. Disponível em: <http://www.corteidh.or.cr/docs/casos/articulos/seriec_72_ing.pdf>. Acesso em: 12 jan. 2018.

CORTE INTERAMERICANA DE DIREITOS HUMANOS. Caso Escher Vs. Brasil. 06 jul. 2009. Disponível em: <http://www.corteidh.or.cr/docs/casos/articulos/seriec_200_por.pdf>. Acesso em: 12 jan. 2018.

CORTE INTERAMERICANA DE DIREITOS HUMANOS. José Pereira Vs. Brasil. 24 out. 2003. Disponível em: <https://cidh.oas.org/annualrep/2003port/Brasil.11289.htm>. Acesso em: 17 jan. 2018.

GRUPO DE ESTUDOS DE DIREITOS HUMANOS. Casos do Tribunal Europeu de Direitos Humanos. Disponível em: <http://gedhjus-ufrj.blogspot.com.br/p/casos-tribunal-europeu-de-direitos.html>. Acesso em: 15 jan. 2018. 
HACHEM, Daniel Wunder. A dupla titularidade (individual e transindividual) dos direitos fundamentais econômicos, sociais, culturais e ambientais. Revista de Direitos Fundamentais e Democracia, Curitiba, v. 14, n. 14, p. 618-688, jul./dez. 2013.

HACHEM, Daniel Wunder. Tutela administrativa efetiva dos direitos fundamentais sociais: por uma implementação espontânea, integral e igualitária. 2014. Tese (Doutorado em Direito)- Universidade Federal do Paraná, Curitiba, 2014.

JURISPRUDÊNCIA DA CORTE INTERAMERICANA DE DIREITOS HUMANOS: Direitos Econômicos, sociais e culturais. Brasília, DF: Ministério da Justiça, 2014. Disponível em: <http://www. corteidh.or.cr/sitios/libros/todos/docs/por1.pdf>. Acesso em: 15 jan. 2018.

LACERDA, Andrey. O diálogo entre as Cortes na Proteção Regional dos Direitos Humanos: Caso Gomes Lunde e ADPF n. 153. Rev. Fac. Direito UFMG, Belo Horizonte, n. 64, p. 105-131, jan./jun. 2014.

LONG, Soraya. Aciertos y desaciertos de la Corte Interamericana de Derechos Humanos en el caso Baena Ricardoy otros vs. Panamá (Caso Ley 25). ano IV, n. 5, dic. 2009. Disponível em: <http://www.corteidh.or.cr/tablas/r24252.pdf>. Acesso em: 15 jan. 2018.

MAZZUOLI, Valério de Oliveira. Curso de Direito Internacional Público. 6. ed. São Paulo: Revista dos Tribunais, 2012.

MAZZUOLI, Valerio de Oliveira. O Controle Jurisdicional da Convencionalidade das Leis. 3. ed. São Paulo: Revista dos Tribunais. 2013.

MAZZUOLI, Valério de Oliveira. O Sistema Regional Europeu de Proteção dos Direitos Humanos. 2010. Disponível em: <http://revistas.unibrasil.com.br/cadernosdireito/index.php/direito/article/ view/520 > . Acesso em: 12 jan. 2018.

MIALON, Marie-France. A Identidade Social Europeia: Dificuldades e Limites da Política Comunitária Social. (2005). Rev. Trib. Reg. Trab. $3^{a}$ Reg., Belo Horizonte, v. 41, n. 71, p. 51-67, jan./jun. 2005.

NUSSBERGER, Angelika. Palestra proferida na Escola Nacional de Formação e Aperfeiçoamento de Magistrados do Trabalho-ENAMAT, em 20 de agosto de 2014, às 16h00. Transcrição realizada pela Divisão de apoio e registro taquigráfico do TST.

OLIVEIRA, Erival da Silva. Direitos Humanos. 4. ed. rev. e atual. São Paulo: Revista dos Tribunais, 2013.

ORGANIZAÇÃO DOS ESTADOS AMERICANOS. Corte Interamericana de Direitos Humanos. Relatório n. 169/11. Caso 1266. 03 nov. 2011. Disponível em: <http://www.oas.org/es/cidh/decisiones/corte/2015/12066FondoPt.pdf>. Acesso em: 11 jan. 2018.

ORGANIZAÇÃO INTERNACIONAL DO TRABALHO. História da OIT. Disponível em: < http:// www.ilo.org/brasilia/conheca-a-oit/hist\%C3\%B3ria/lang--pt/index.htm>. Acesso em: 12 dez. 2017.

PIOVESAN, Flávia. Ações afirmativas da perspectiva dos direitos humanos. Cadernos de Pesquisa, São Paulo, v. 35, n. 124, jan./abr. 2005. 
PIOVESAN, Flavia. Direitos Humanos e o Direito Constitucional Internacional. 12. ed. São Paulo: Saraiva, 2011.

PIOVESAN, Flávia. Força integradora e catalizadora do sistema interInteramericano de protecção dos direitos humanos: desafios para a pavimentação de um constitucionalismo regional. In: SOUSA, Marcelo Rebelo de et al. (Org.). Estudos de Homenagem ao Prof. Doutor Jorge Miranda. Coimbra: Coimbra Editora, 2012.

PIOVESAN, Flavia. Sistema Interamericano de direitos humanos: impacto transformador, diálogos jurisdicionais e os desafios da reforma. REDES-Revista Direitos Emergentes na Sociedade Global, v. 3, n. 1, jan./jun. 2014. Disponível em: <www.ufsm.br/redesg >. Acesso em: 12 dez. 2017.

PRONER, Carol. Sistema Internacional de Proteção de Direitos Humanos: A Efetividade dos Direitos Econômicos Sociais e Culturais. Caderno da Escola de Direito e Relações Internacionais da Unibrasil, n. 7, jan./dez. 2007.

RAMOS FILHO, Wilson. Direito Capitalista do Trabalho: História, Mitos e Perspectivas no Brasil. São Paulo: LTR, 2012.

SCOOT, Rebeca J. Scott. O Trabalho Escravo Contemporâneo e os Usos da História. Mundos do Trabalho. Florianópolis, v. 5, n. 9, 2013.

SILVEIRA FILHO, Alex Sandro da. O massacre do Eldorado de Carajás e a violência rural no brasil hoje. Núcleo de direitos humanos, Universidade do Vale dos Sinos, 23 abr. 2015. Disponível em: <http://unisinos.br/blogs/ndh/2015/04/23/o-massacre-de-eldorado-dos-carajas-e-a-violencia-rural-no-brasil-hoje/>. Acesso em: 17 jan. 2018.

STRAPAZZON, Carlos Luiz; BELLINETTI, Luiz Fernando; COUTINHO, Sergio Mendes. Eficácia de Direitos Fundamentais nas Relações do trabalho, sociais e empresariais. In: CONGRESSO NACIONAL DO CONPEDI, 24., 2015. Anais... Belo Horizonte, 2015. Disponível em: < http://www. conpedi.org.br/publicacoes/66fsl345/6eh993o0/8YTwzQ32FAE386wC.pdf>. Acesso em: 16 jan. 2018.

TOJO, Liliana; LIMA Ana Luísa. Brasil e o Sistema Interamericano de Direitos Humanos. 2004. Disponível em: <http://www.social.org.br/relatorio2004/relatorio037.htm>. Acesso em: 13 jan. 2018.

TRIBUNAL AFRICANO DE DIREITOS HUMANOS E DOS POVOS. 001/08 Michelot Yogogombaye v. A República Do Senegal. 15 dez. 2009. Disponível em: < http://pt.african-court.org/images/Cases/Judgment/PT_App\%20001-2008\%20Judgment.pdf>. Acesso em: 18 de mar. 2018.

TRIBUNAL AFRICANO DE DIREITOS HUMANOS E DOS POVOS. 012/11 National Convention of Teachers Trade Union (CONASYSED) v. Gabon. 15 dez. 2011. Disponível em: <http://caselaw. ihrda.org/doc/012.11/view/en/>. Acesso em: 18 jan. 2018.

TRIBUNAL AFRICANO DE DIREITOS HUMANOS E DOS POVOS. 221/98 Alfred B. Cudjoe / Ghana. 05 maio 1998. Disponível em: <http://caselaw.ihrda.org/doc/221.98/>. Acesso em: 10 jan. 2018.

TRIBUNAL AFRICANO DE DIREITOS HUMANOS E DOS POVOS. 226/99 Union Nationale des Syndicats Autonomes du Sénégal (UNSAS) / Senegal. 1999. Disponível em: <http://caselaw.ihrda. org/doc/226.99/>. Acesso em: 19 jan. 2018. 
TRIBUNAL AFRICANO DE DIREITOS HUMANOS E DOS POVOS. 247/02 - IHRDA (on behalf of Jean Simbarakiye) Vs. Democratic Republic of Congo. 2002. Disponível em: <http://www.ihrda. org/2013/09/24702-ihrda-on-behalf-of-jean-simbarakiye-democratic-republic-of-congo-2/>. Acesso em: 17 jan. 2018.

TRIBUNAL AFRICANO DE DIREITOS HUMANOS E DOS POVOS. 292/04 IHRDA (em nome de Esmaila Connateh e 13 outros) Vs. República de Angola. 2004. Disponível em: <http://www.ihrda. org/wp-content/uploads/2011/02/292-04-IHRDA-_em-nome-de-Esmaila-Connateh-e-13-outros_-c-Angola-portugu\%C3\%AAs.pdf>. Acesso em: $17 \bar{j}$ jan. 2018.

TRIBUNAL AFRICANO DE DIREITOS HUMANOS E DOS POVOS. 335/06 Dabalorivhuwa Patriotic Front v the Republic of South Africa. 2006. Disponivel em: <http://caselaw.ihrda.org/ doc/335.06/>. Acesso em: 18 jan. 2018.

Data da submissão: 14 de dezembro de 2016 Avaliado em: 27 de dezembro de 2016 (AVALIADOR A) Avaliado em: 15 de abril de 2018 (AVALIADOR B) Aceito em: 15 de abril de 2018 